\title{
Social Behaviour, Vocalization and Conservation of Narwhals
}

\author{
by Marianne Marcoux
}

\section{INTRODUCTION}

$\mathrm{L}$ IVING IN GROUPS IS HIGHLY BENEFICIAL FOR INDIVIDUALS of social species. Group living improves resource acquisition (Creel and Creel, 1995), vigilance, and defence against predators (e.g., Bertram, 1980), as well as enhancing the care of the offspring (Clutton-Brock, 2002). In some species, such as African elephants (Loxodonta africana; Wittemyer et al., 2005) and resident killer whales (Orcinus orca; Bigg et al., 1990), individuals form permanent groups that they keep for their entire life. Groups can differ in behaviours that affect their fitness, such as their food preferences and hunting techniques, or in the use of tools (Whiten et al., 1999). In some groups, older individuals possess ecological knowledge that they share only with the rest of their group, which gives fitness advantages to the members of that group (Payne, 2003). Thus, group membership may ultimately affect individual survival.

Communication is crucial to all social species. Communication helps to synchronize the behaviour of members of a group and allows for individual or group recognition or both. Individual recognition through vocal signatures is a widespread form of social communication among mammals (e.g., Goldman et al., 1995) and may be used as contact calls to keep group cohesion in fluid fusion-fission groups (e.g., Connor et al., 2000). Group-specific calls are common in social marine mammals whose individuals have strong, long-term bonds with the members of their group (e.g., Rendell and Whitehead, 2003). Thus, the characteristics and differences in vocalization are closely linked to group organization of social species.

The narwhal (Monodon monoceros), a gregarious, toothed whale, has a strictly Arctic distribution and is commonly found between $70^{\circ}$ and $80^{\circ} \mathrm{N}$ (Reeves and Tracey, 1980). Narwhals spend half of the year in extremely dense pack ice $(<3 \%$; Laidre and Heide-Jørgensen, 2005) and their movements and diving behaviour are influenced by ice coverage (Laidre et al., 2004). They undergo seasonal migrations from their wintering grounds in Baffin Bay and northern Davis Strait to their summer ranges in the deep fjords of Greenland and Baffin Island (Dietz et al., 2001). During the spring migration, narwhals travel in groups of several hundreds (Silverman, 1979) while when in the fjords they form groups of about three individuals (Cosens and Dueck, 1991).

The narwhal is a highly vocal species that emits two different kinds of vocalizations (Ford and Fisher, 1978). Pulsed sounds (clicks) are believed to be used, as in other toothed whales, for spatial orientation and echolocation of prey ( $\mathrm{Au}, 1993)$. Narwhals also produce frequencymodulated whistles and burst-pulsed sounds, which are associated with social communication in other cetaceans

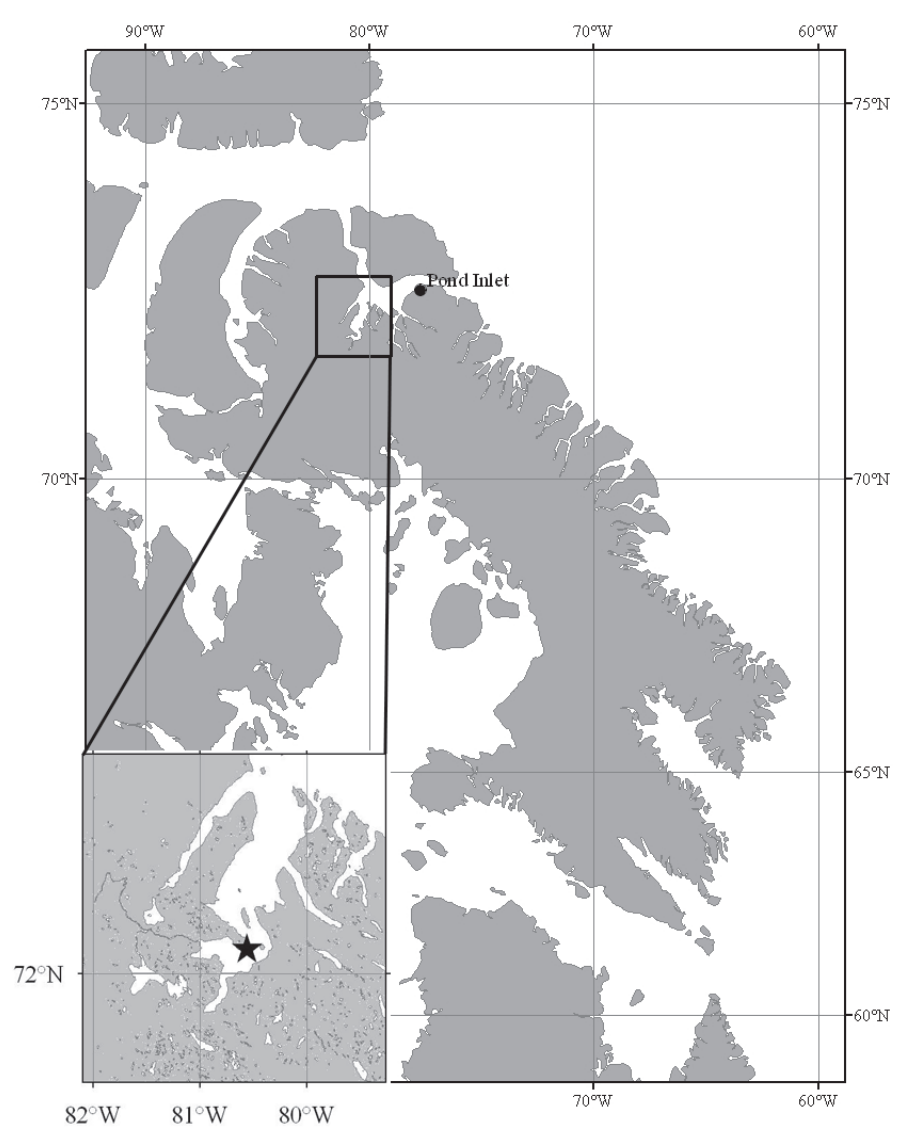

FIG. 1. Map of the study site in northern Baffin Island. The star represents the peninsular vantage point from which the observations were made.

(Herzing, 2000). It was suggested that whistles in narwhals might be a form of individual or group signature (Shapiro, 2006). Because narwhals are highly social and live in aquatic environments in which acoustic cues are most effective in transmitting information, vocal communication is likely to be particularly important for this species.

Narwhals are facing a rapidly changing environment that could affect their population trends. On the basis of an index of habitat requirements, and from evidence for biological and demographic responses to climate change, the narwhal was ranked among Arctic and Subarctic marine species as one of the most sensitive to climate change (Laidre et al., 2008). Narwhals are also being affected by accelerated industrial exploitation of natural resources, which is often associated with an increased number of ships within their range. Shipping traffic has been shown to disturb other marine mammal species by altering their direction of travelling (Bejder et al., 1999), behaviour (Lusseau, 2006; Stockin et al., 2008), and breathing patterns (Nowacek et al., 2001), as well as the spread of their 
groups (Bejder et al., 1999; Nowacek et al., 2001). Moreover, cetaceans rely on sounds for navigation, foraging, and communication, and noise pollution caused by shipping has been shown to be highly damaging for them (for a review see Weilgart, 2007).

Several key aspects of narwhal biology and behaviour are still unknown. Narwhals have been listed as "near threatened" by the International Union for Conservation of Nature (IUCN) (Jefferson et al., 2008) and as "special concern" by the Committee on the Status of Endangered Wildlife in Canada (COSEWIC, 2004). With my research project, I am aiming to fill some of these knowledge gaps by 1) describing the grouping patterns of narwhals, 2) characterizing and categorizing their vocalizations, 3) assessing the impact of shipping activity on their vocal and behavioural activity, and 4) estimating their population size.

\section{METHODS AND PRELIMINARY RESULTS}

My study area is in Koluktoo Bay, a 200 m deep bay near the hamlet of Pond Inlet. All data were collected from a peninsula shoreline (Bruce Head, 72 ${ }^{\circ} 04^{\prime} \mathrm{N}, 80^{\circ} 32^{\prime} \mathrm{W}$, Fig. 1) with a high vantage point, during the summers of 2006 to 2008. The narwhals swim very close to the peninsula when they enter and exit the bay, which allows us to observe their behaviour without disturbing them. Narwhals tend to gather in the bay and remain there for a few hours to a few days.

\section{GROUPING PATTERNS AND BEHAVIOUR}

In order to characterize the groups, I note the size of the groups and their composition. Because narwhals change in coloration with age (Fig. 2a-c), it is possible to classify them into age groups. The presence of a tusk usually indicates a male (Fig. 2d). I observe the behavioural state (travelling, milling, socializing, feeding, or resting) of the majority of group members, as well as some specific events (e.g., tusk above water, breaching). Variables such as the distance between the members of the group and the breathing sequence are also noted to monitor the natural behaviour of narwhals. I have observed over 3000 groups to date, which have varied considerably in size and composition. The average group size is 3.6 animals (range $=2$ to 25 ). Narwhals were sometimes segregated by sex and age categories, but also formed groups of mixed composition. The majority of the narwhals I have observed were travelling.

\section{VOCALIZATIONS}

I use a passive hydrophone to record the underwater vocalizations of the narwhals (Fig. 3). To characterize the calls, I measure different parameters, such as minimum and maximum frequency, number of inflections, duration, and

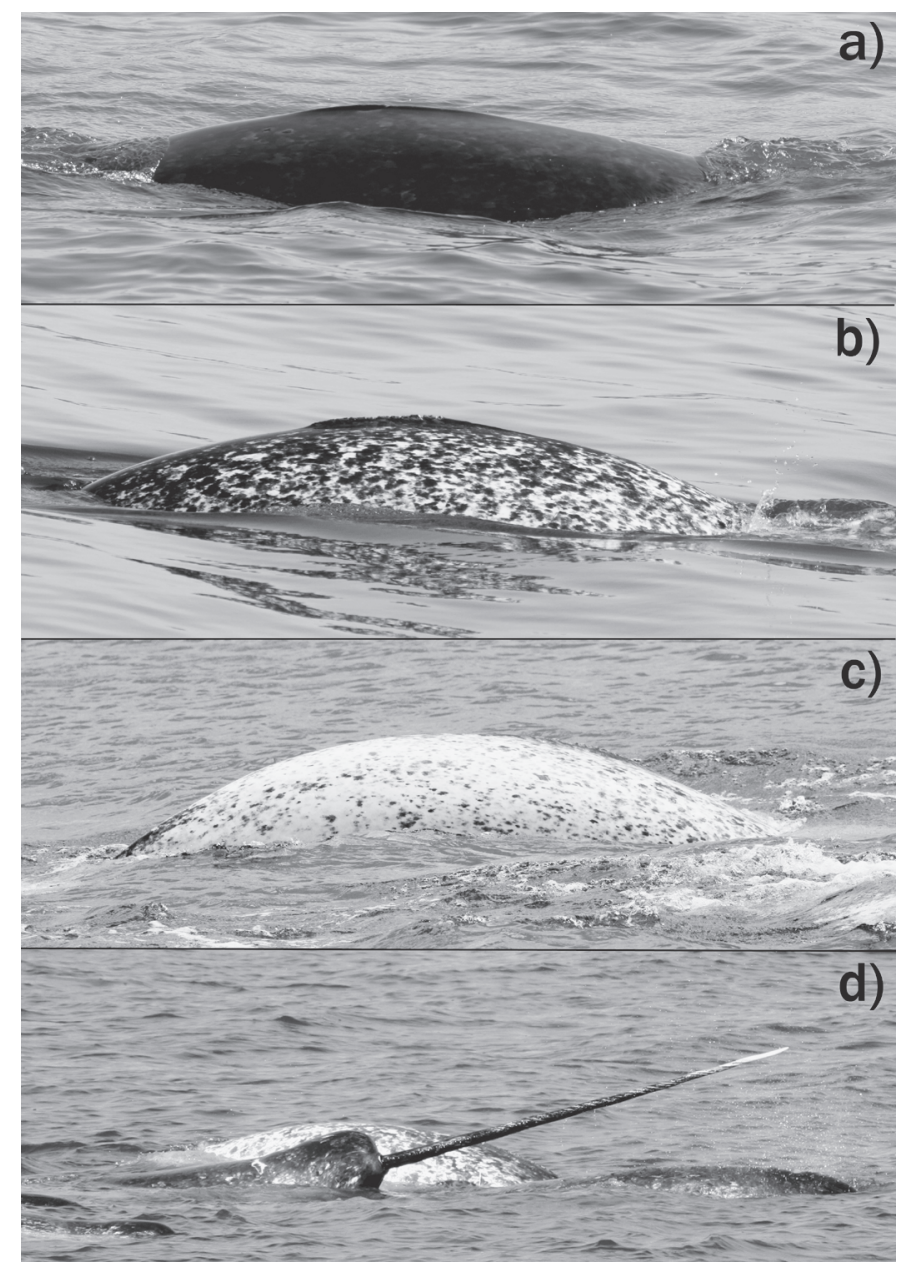

FIG. 2. Features that allow us to differentiate the age group and sex of narwhals include the coloration patterns of a) a juvenile, b) an adult, and c) an old adult, as well as d) the tusk of a male.

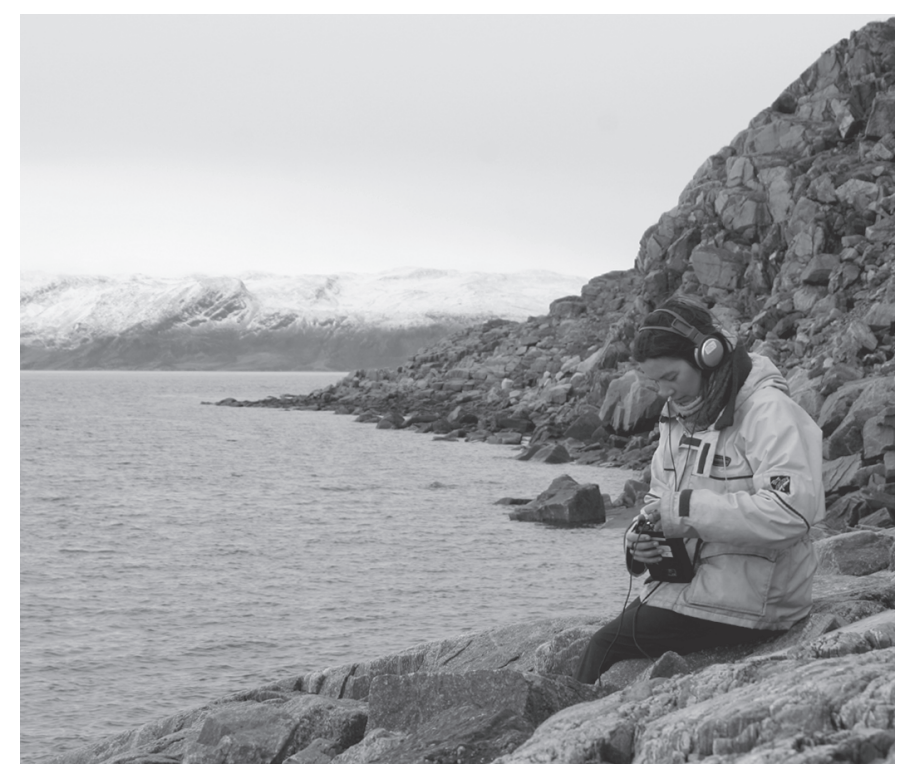

FIG. 3. Marianne Marcoux connecting the hydrophone to the recorder for underwater recording of narwhal vocalizations. 


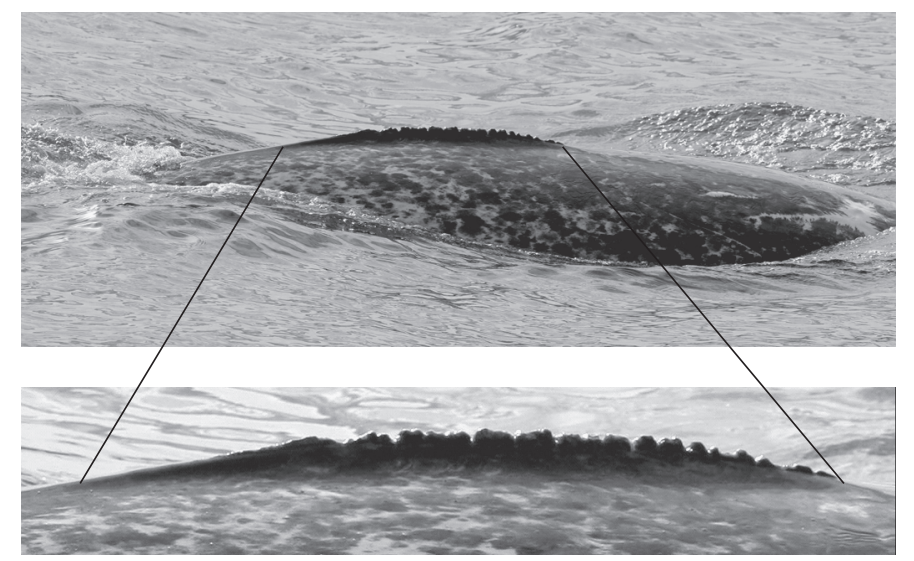

FIG. 4. a) Dorsal ridge of an adult narwhal, with b) the notches that are used for photo-identification.

repetition rates. I investigate differences in the vocalizations while the narwhals are exhibiting different behaviours, as well as differences among groups of narwhals showing the same behaviour. This information is highly valuable for acoustic monitoring. By knowing the characteristics of the calls and their functions, we can create a sound detector that can be used to infer the behavioural state of the narwhals and the structure of the population (Rendell et al., 1999). This tool is especially valuable for species (like the narwhal) that are difficult to observe regularly, especially during the dark, frozen winters.

\section{MONITORING THE IMPACT OF SHIPPING}

With increased shipping traffic in northern Baffin Island, I am also evaluating the short-term effects of shipping on narwhals. I compare the behavioural state, breathing rates, and group composition of the narwhals before, during, and after the passage of ships and infer possible impacts from changes in those variables. Since shipping is associated with underwater noises, which are thought to mask the vocalizations in other cetacean species (Lesage et al., 1999; Buckstaff, 2004), I also compare the vocalizations of the narwhal when ships are present and absent. A good understanding of the possible effects of shipping will help to mitigate its possible impacts on this narwhal population.

\section{POPULATION SIZE ESTIMATE}

I use photo-identification to estimate the size of the population of narwhals. Although this method is widely used for marine mammals (e.g., Hammond et al., 1990), it has never been used with the narwhal. I am working in collaboration with Dalhousie graduate student M. AugerMéthé (2008), who developed the technique of using the notches on the dorsal ridge of narwhals as permanent features unique to each individual (Fig. 4). We have created a catalogue with photographs of individual narwhals and additional information, such as the date and location of the photograph and the number of photographs taken of the same individual. I will apply mark-recapture models to the data in this catalogue to estimate the number of narwhals passing Bruce Head.

\section{RELEVANCE}

The narwhal is a species of great cultural and economic importance to Pond Inlet and other northern communities. The narwhal is hunted by members of the community now as it has been for several centuries. Its skin and blubber (muktuk) provide various nutrients, including protein, fat, and vitamins, and its ivory is sold intact or carved (Reeves, 1992; pers. observ.). The hunt is an important and exciting activity that allows members of the community to connect with the land and their traditions. During interviews, elders and hunters from Pond Inlet indicated that they highly value narwhals and hope to maintain their hunt (pers. observ.).

This study will provide insights into some poorly resolved aspects of the narwhal biology, such as their grouping patterns and vocalizations, as well as give indications of their sensitivity to shipping disturbance. In a rapidly changing environment, baseline information is highly valuable and helps to monitor changes. A better understanding of narwhal biology is critical to both marine mammal science and narwhal conservation.

\section{ACKNOWLEDGEMENTS}

I am most grateful to be the recipient of the Lorraine Allison Scholarship of the Arctic Institute of North America. Other funding was provided by the Canadian Wildlife Federation, the Canadian Marine Environment Protection Society, the Canadian Whale Institute, an Eben Hopson Fellowship, the Natural Science and Engineering Research Council of Canada, the Northern Scientific Training Program, and the World Wildlife Fund Canada. Thanks to M. Auger-Méthé and my supervisor M. Humphries, as well as my committee members, C. Chapman and R. Krahe. I wish to thank the community of Mittimatalik for welcoming me to do research on their land; N. Inuarak, A. Kublu, and L. Suskluk for their guiding services; and K. Beardsley for help in the field. This research would not be possible without the logistical support of Polar Sea Adventures. I wish to thank S. Ferguson and R. Antunes for lending research equipment.

\section{REFERENCES}

AU, W.W.L. 1993. The sonar of dolphins. New York: Springer. AUGER-MÉTHÉ, M. 2008. Photo-identification of narwhals. MSc thesis, Dalhousie University, Halifax, Nova Scotia. 
BEJDER, L., DAWSON, S.M., and HARRAWAY, J.A. 1999. Responses by Hector's dolphins to boats and swimmers in Porpoise Bay, New Zealand. Marine Mammal Science 15(3): $738-750$.

BERTRAM, B.C.R. 1980. Vigilance and group-size in ostriches. Animal Behaviour 28:278-286.

BIGG, M.A., OLESIUK, P.F., ELLIS, G.M., FORD, J.K.B., and BALCOMB, K.C. 1990. Social organization and genealogy of resident killer whales (Orcinus orca) in the coastal waters of British Columbia and Washington State. Report of the International Whaling Commission 12:383-405.

BUCKSTAFF, K.C. 2004. Effects of watercraft noise on the acoustic behavior of bottlenose dolphins, Tursiops truncatus, in Sarasota Bay, Florida. Marine Mammal Science 20(4): $709-725$.

CLUTTON-BROCK, T. 2002. Behavioral ecology-Breeding together: Kin selection and mutualism in cooperative vertebrates. Science 296(5565):69-72.

CONNOR, R.C., WELLS, R.S., MANN, J., and READ, A.J. 2000. The bottlenose dolphin: Social relationships in a fission-fusion society. In: Mann, J., Connor, R.C., Tyack, P.L., and Whitehead, H., eds. Cetacean societies: Field studies of dolphins and whales. Chicago: The University of Chicago Press. 91-126.

COSENS, S.E., and DUECK, L.P. 1991. Group size and activity patterns of belugas (Delphinapterus leucas) and narwhals (Monodon monoceros) during spring migration in Lancaster Sound. Canadian Journal of Zoology 69(6):1630-1635.

COSEWIC (COMMITTEEONTHESTATUS OFENDANGERED WILDLIFE IN CANADA). 2004. COSEWIC assessment and update status report on the narwhal Monodon monoceros in Canada. Ottawa: COSEWIC. vii + 50 p.

CREEL, S., and CREEL, N.M. 1995. Communal hunting and pack size in African wild dogs, Lycaon pictus. Animal Behaviour 50:1325-1339.

DIETZ, R., HEIDE-JØRGENSEN, M.P., RICHARD, P.R., and ACQUARONE, M. 2001. Summer and fall movements of narwhals (Monodon monoceros) from northeastern Baffin Island towards northern Davis Strait. Arctic 54(3):244-261.

FORD, J.K.B., and FISHER, H.D. 1978. Underwater acoustic signals of narwhal (Monodon monoceros). Canadian Journal of Zoology 56(4):552-560.

GOLDMAN, J.A., PHILLIPS, D.P., and FENTRESS, J.C. 1995. An acoustic basis for maternal recognition in timber wolves (Canis lupus). Journal of the Acoustical Society of America 97(3):1970-1973.

HAMMOND, P.S., MIZROCH, S.A., and DONOVAN, G. P. 1990. Individual recognition of cetaceans: Use of photo-identification and other techniques to estimate population parameters. Report of the International Whaling Commission, Special Issue 12. Cambridge: International Whaling Commission.

HERZING, D.L. 2000. Acoustic and social behavior of wild dolphins: Implications for a sound society. In: Au, W.W.L., Popper, A.N., and Fay, R.R., eds. Hearing by whales and dolphins. New York: Springer-Verlag. 225-273.

JEFFERSON, T.A., KARCZMARSKI, L., LAIDRE, K., O'CORRY-CROWE, G., REEVES, R.R., ROJAS-BRACHO, L., SECCHI, E.R., SLOOTEN, E., SMITH, B.D., WANG, J.Y., and ZHOU, K. 2008. Monodon monoceros. In: 2008 IUCN Red List of Threatened Species. http://www.iucnredlist.org/details/ 13704.

LAIDRE, K.L., and HEIDE-JØRGENSEN, M.P. 2005. Arctic sea ice trends and narwhal vulnerability. Biological Conservation 121:509-517.

LAIDRE, K.L., HEIDE-JØRGENSEN, M.P., LOGSDON, M.L., HOBBS, R.C., DIETZ, R., and VanBLARICOM, G.R. 2004. Fractal analysis of narwhal space use patterns. Zoology 107: $3-11$.

LAIDRE, K.L., STIRLING, I., LOWRY, L.F., WIIG, Ø., HEIDEJØRGENSEN, M.P., and FERGUSON, S.H. 2008. Quantifying the sensitivity of Arctic marine mammals to climate-induced habitat change. Ecological Applications 18(2):S97-S125.

LESAGE, V., BARRETTE, C., KINGSLEY, M.C.S., and SJARE, B. 1999. The effect of vessel noise on the vocal behavior of belugas in the St. Lawrence River estuary, Canada. Marine Mammal Science 15(1):65-84.

LUSSEAU, D. 2006. The short-term behavioral reactions of bottlenose dolphins to interactions with boats in Doubtful Sound, New Zealand. Marine Mammal Science 22(4):802-818.

NOWACEK, S.M., WELLS, R.S., and SOLOW, A.R. 2001. Shortterm effects of boat traffic on bottlenose dolphins, Tursiop truncatus, in Sarasota Bay, Florida. Marine Mammal Science 17(4):673-688.

PAYNE, K. 2003. Sources of social complexity in the three elephant species. In: de Waal, F.B.M., and Tyack, P.L., eds. Animal social complexity: Intelligence, culture, and individualized societies. Cambridge, Massachusetts: Harvard University Press. $57-86$

REEVES, R.R. 1992. What is a narwhal worth? An analysis of factors driving the narwhal hunt and a critique of tried approaches to hunt management for species conservation. $\mathrm{PhD}$ thesis, McGill University, Montreal, Quebec.

RENDELL, L., and WHITEHEAD, H. 2003. Vocal clans in sperm whales (Physeter macrocephalus). Proceedings of the Royal Society London, B-Biological Sciences 270(1512):225-231.

RENDELL, L.E., MATTHEWS, J.N., GILL, A., GORDON, J.C.D., and MACDONALD, D.W. 1999. Quantitative analysis of tonal calls from five odontocete species, examining interspecific and intraspecific variation. Journal of Zoology, London 249: 403 - 410.

SHAPIRO, A.D. 2006. Preliminary evidence for signature vocalizations among free-ranging narwhals (Monodon monoceros). Journal of the Acoustical Society of America 120(3):1695-1705.

SILVERMAN, H.B. 1979. Social organization and behaviour of the narwhal, Monodon monoceros L. in Lancaster Sound, Pond Inlet, and Tremblay Sound, N.W.T. MSc thesis, McGill University, Montreal, Quebec.

STOCKIN, K.A., LUSSEAU, D., BINEDELL, V., WISEMAN, N., and ORAMS, M.B. 2008. Tourism affects the behavioural budget of the common dolphin Delphinus sp. in the Hauraki Gulf, New Zealand. Marine Ecology Progress Series 355: 287-295.

WEILGART, L.S. 2007. The impacts of anthropogenic ocean noise on cetaceans and implications for management. Canadian Journal of Zoology 85(11):1091 - 1116. 
WHITEN, A., GOODALL, J., McGREW, W.C., NISHIDA, T., REYNOLDS, V., SUGIYAMA, Y., TUTIN, C.E.G., WRANGHAM, R.W., and BOESCH, C. 1999. Cultures in chimpanzees. Nature 399(3767):682-685.

WITTEMYER, G., DOUGLAS-HAMILTON, I., and GETZ, W.M. 2005. The socioecology of elephants: Analysis of the processes creating multitiered social structures. Animal Behaviour 69:1357-1371.

Marianne Marcoux, a doctoral student in the Department of Natural Resource Sciences, McGill University, is the recipient of the Lorraine Allison Scholarship for 2008. 